\title{
Kunst, kapitalisme, revolution og kommunisering
}

\section{Om overskridelsen af kunsten som betydning uden virkelighed}

Hvis revolutionen skal finde sted, skal mennesket gå fra ti til elleve fingre.

Pierre Guyotat

Slutte sig til det, man erfarer som rigtigt. Og starte derfra. Le comité invisible

Et af de afgørende kendetegn ved moderne kunst - og kunst bliver jo til kunst i vores forstand med moderniteten og kapitalismen, idet den løsrives fra religiøst institutionelle og feudale sammenhænge - har hele tiden været dens umiddelbart politiske dimension eller dens relation til revolutionen. Som André Breton og Leo Trotskij skriver i deres manifest "Pour un art révolutionnaire indépendant": "Vi vurderer, at kunstens højeste opgave [...] er at deltage bevidst og aktivt i forberedelsen af revolutionen" (Breton \& Trotskij, 337). Fra den tyske romantik og frem er kunst af filosofien blevet udstyret med en autonom status, der har gjort kunst til en sfære, hvor der foregår en intens og unik kritisk og selvkritisk praksis, der ikke blot bearbejder og kommenterer sociale og politiske forhold, men også kunstens egne problemer og begrænsninger. Men kunstens autonomi er både en mulighed og en forbandelse. Takket være den er kunstneren på den ene side ikke underlagt eksternt formulerede regler eller forordninger, men autonomien har på den anden side også en indbygget begrænsning, da den betyder, at den kunstneriske praksis reelt har en begrænset social virkning. Som den tyske litteraturhistoriker Peter Bürger skriver, er kunst løsrevet fra dagliglivet og derfor uden håndgribelig effekt (Bürger, 17).

Kunst er således kun i begrænset omfang politisk eller er kendetegnet ved en begrænset politik; det er i hvert fald de kunstneriske avantgarders læsning af kunstens autonomi. Derfor blev deres projekt i 1910'erne og 1920'erne at integrere kunst og liv og problematisere og helst afvikle kunstens autonomi som led i en omfattende revolutionær transformation, hvor det moderne livs uddifferentiering blev omgjort, således at det (igen?), som Marx skriver, blev muligt "at gå på jagt om morgenen, 
fiske om eftermiddagen, beskæftige mig med kvægavl om aftenen, kritisere oven på middagen, netop hvad jeg har lyst til, uden nogen sinde at blive, jæger, fisker, hyrde eller kritiker" (Marx, 42). Målet for avantgardens romantiske antikapitalisme var at omgøre uddifferentieringen og ophæve den udparcellering af forskellige erfaringer og opdelingen af det menneskelige liv i relativt adskilte sfærer, der kendetegner livet i det moderne samfund. ${ }^{\mathrm{I}}$ Men det vigtige i denne sammenhæng er, at avantgardebevægelsernes voldsomme angreb på kunstinstitutionen og forsøgene på at lade kunst og liv smelte sammen reelt blot var en anden version af den moderne kunstideologi, hvor kunsten er udstyret med transformative, endda revolutionære kræfter. Avantgarderne abonnerede således stadigvæk på forestillingen om kunst som værende i besiddelse af et kritisk potentiale; det var netop derfor, det var nødvendigt at bryde ud af institutionen og affirmere den oprindelige romantiske idé om en genfortryllet verden. ${ }^{2}$ Kunst var en subversiv kraft, nu blot for så vidt som den ikke længere var forankret i kunstinstitutionen. For at være tro mod sig selv måtte kunsten ophæve sig selv og kunstinstitutionen og tage del i en altomfattende omkalfatring af det borgerligt kapitalistiske samfund. Det var derfor, at mellemkrigstidens avantgardegrupper som dada og surrealisterne var involveret i fors $\varnothing \mathrm{g}$ på at udfordre kunstinstitutionen; alle udfordringerne fandt sted med henblik på at lade den kreativitet, kunstneren var blevet udstyret med som led i konstitueringen af kunsten som autonom sfære, sive ud i dagliglivet. Det var derfor, avantgarderne latterliggjorde kunstnerrollen og -identiteten og forsøgte at ophæve den til fordel for en aktivering af beskueren, der ellers passivt blot stod og kontemplerede kunstnerens efterladenskaber, som dermed på én gang pegede på et andet samfund og en sammenhængende tilværelse, men samtidig bekræftede det etablerede og dets opdeling i arbejde og kunst.

\section{Brudte løfter}

Denne dobbelthed ved kunsten kortlagde den tyske filosof og medlem af Frankfurterskolen Herbert Marcuse allerede i midten af 1930'erne i "Über den affirmativen Charakter der Kultur". På den ene side er kunst ifølge Marcuse i besiddelse af eller kan give form til en utopisk dimension, den kan skabe billeder af en anden verden, selvom den er et produkt af denne verden. Den indeholder - med et citat af Stendahl som flere medlemmer af Institut für Sozialforschung var svært glade for - "une promesse de bonheur" (Marcuse, 210). Kunst er således et udtryk for menneskets optagethed af egen fremtidig lykke, og den transcenderer i den forstand på et symbolsk niveau samfundet. Den er en art fristed, hvor en række fundamentale behov, som knægtes i det kapitalistiske samfund, virtuelt indfries. Ofrene for det borgerlige samfunds rationalisering, som ensretter og opdeler det menneskelige liv og marginaliserer menneskets spontane kreativitet, kommer til orde og vækkes til live i kunsten, der på den måde ifølge Marcuse fungerer som et helle eller en losseplads for udgrænsede erfaringer og udtryk. Den moderne kunst er altså i besiddelse af et subversivt potentiale ifølge Marcuse.

Men i overensstemmelse med den kritiske teoris marxisme anlægger Marcuse et perspektiv på kunst, som betoner dens funktion i en bredere kontekst i rammen 
af etableringen af det moderne samfund, hvor rationalisering og uddifferentiering er kodeordene. Inden for denne ramme er kunst det sted, hvor den anarkistiske fantasi, der hastigt udraderes af en accelereret rationaliseringsproces, overvintrer, men også forhindres $\mathrm{i}$ at få social breddevirkning, netop fordi den er spærret inde i kunsten. I modsætning til den tyske kulturvidenskabelige tradition, som tenderer til at analysere kunst og kultur i en form for socialt vakuum, hvor kunst er en sfære for sig, og vel at mærke en ophøjet sfære, så interesserer Marcuse sig nemlig for kunstens samfundsmæssighed og analyserer, som de andre medlemmer af Frankfurterskolen også gjorde det, kunst som et sprog, hvori sociale processer kommer til udtryk i kodet form. Det betyder ikke, at Marcuse blot ser kunst som en afspejling af sociale forhold, men at han lige nøjagtig betoner kunstens dobbelthed, det forhold at den er relativt autonom og både protesterer mod det kapitalistiske samfund og dets fremmedgørende abstraktioner og samtidig bekræfter dette samfund, idet den fungerer som en ventil, hvorigennem samfundet kan slippe af med overskydende energi og lade udgrænsede begær komme til udtryk som formålsløse luksusvarer uden fare for reelle ændringer, som betydning uden virkelighed. I det moderne kapitalistiske samfund er kunsten altså ifølge Marcuse karakteriseret ved en historisk specifik dobbelthed: Den er både en institutionelt afgrænset 'fri' sfære og produktionen af luksusvarer. Disse to aspekter er uforenelige, og de kunstværker, der virker, afviser ethvert forsøg på forsoning af autonomi og marked og forbliver splittede. Denne dobbelthed benævner Marcuse "kunstens affirmative karakter", på den ene side eksponerer kunsten "glemte sandheder", på den anden side fremvises disse sandheder i det æstetiske skins medium i en sfære adskilt fra dagliglivet. Paradokset er således, at kunst stabiliserer de selvsamme forhold, som den kritiserer. Dens autonomi sætter sig igennem som en neutralisering. ${ }^{3}$ Der bliver skabt "et rige af tilsyneladende enhed og frihed $\mathrm{i}$ hvilket tilværelsens antagonistiske forhold stabiliseres og pacificeres. Kulturen bejaer og skjuler de nye samfundsmæssige livsbetingelser" (193).

Kunstneren har en større udtryks- og ytringsfrihed end almindelige mennesker i et borgerligt kapitalistisk samfund, skriver Marcuse. "Det, der i den virkelige verden er utopi, fantasi og oprør, er tilladt i kunsten”, men kun så længe det forbliver adskilt fra dagliglivet og optræder under etiketten 'kunst' (210). Den affirmative kultur opretholder ganske vist billedet af en anden verden, men den forankrer løftet om lykke og frihed i en adskilt sfære, der er løsrevet fra dagliglivet og politisk praksis og kompenserer på den måde æstetisk for den faktisk eksisterende ufrihed, udbytning og fremmedgørelse. Som Marcuse kritisk konkluderer": "Kunstens skønhed er [...] forenelig med den dårlige nutid" (213). Ikke desto mindre fastholder Marcuse, at kunst protesterer mod den dårlige nutid, at dens løfte om lykke er et tegn på fraværet af lykke i det bestående, den moderne kunst er ikke blot falsk bevidsthed eller ideologi, som visse dogmatiske marxister fastholder. Moderne kunst kan være en immanent kritik af den borgerlige ideologi, den selv er udtryk for, en kritik der kan medvirke til en revolutionær forandring, fremfører Marcuse. Den kan ifølge Marcuse være "den store afvisning", "den totale negations metasprog", frigørelsen af menneskets sanser hinsides kapitalismens fremmedgørende og afhængighedsskabende strukturer. Men for Marcuse er der ikke tvivl om, at det kun er for så vidt, at den moderne kunst i trods og mod alle odds evner denne kritik af det kapitalistiske sam- 
fund og peger ud over det, at den er af betydning, ellers er den blot en bekræftelse af den allerede etablerede orden, og så er vi ilde stedt. Marcuses begreb om kunstens affirmative karakter viser således eksemplarisk, hvorledes kunsten udstyres med muligheden for at udgøre en art æstetisk systemkritik, der peger ud over den etablerede virkelighed, men også risikerer at bekræfte den allerede etablerede smag og den kapitalistisk definerede verden, hvor kunst bliver rum for erfaringer, der er udgrænset af andre dele af det menneskelige liv. Derfor er det både svært nødvendigt at opretholde kunstens autonomi i dårlige tider og kæmpe imod dens respektable inkorporering i det endimensionelle samfunds kultur, men det er samtidig slet ikke nok, når det kommer til stykket. Autonomien gør jo den negative bevidsthed stump, og kun en overskridelse af den kan virkeliggøre kunstens oprindelige drøm om et ikke-fremmedgjort, sammenhængende liv. Kunst og revolution er med andre ord snævert forbundne.

\section{Kulturindustri version 2.0}

Marcuses forestilling om det store brud og avantgardebevægelsernes revolutionære tilsidesættelse af kunstinstitutionen synes imidlertid i høj grad at være forsvundet. Hvis kunsten nogensinde har været i stand til at skabe en revolution eller medvirke til en sådan, så ser det ud som om, det er ganske længe siden. I dag fungerer kunst i stedet mestendels som en integreret del af en udvidet oplevelsesøkonomi, hvor kunst er uskelnelig fra andre former for kulturturisme og storbybranding. Kunstens autonomi er således under intenst pres. Det er derfor, at Marcuse og Frankfurterskolens tekster om kunst i dag har et næsten melankolsk skær. Politisk har kontrarevolutionen de bedste kort på hånden, og inden for kunsten er presset fra kulturindustrien stærkere end nogensinde, om end det ikke betyder, at kunstens autonomi helt er ophævet. Men det er vitterligt svært at opretholde forestillingen om, at der er en afgørende forskel på kunsten, og hvad Theodor Adorno og Max Horkheimer i 1940'erne kaldte kulturindustrien (jf. Adorno \& Horkheimer).

Et af de signifikante eksempler på denne udvikling hen imod, hvad vi kan kalde kulturindustri version 2.0, har uden tvivl været fremkomsten af forestillingen om kunst og kultur som en ny vigtig økonomisk ressource. Med henvisning til bl.a. den amerikanske urbanitetsteoretiker Richard Floridas idé om den kreative klasse blev kunstens og kulturens rolle i skabelsen af værdi i byen og økonomisk udvikling generelt synliggjort og hypostaseret, og der blev åbnet for en sammensmeltning af byudvikling og kulturindustri (jf. Harvey, Deutsche og Peck). Knopskydningen af museer og kulturinstitutioner verden rundt er blot et af eksemplerne på den gennemslagskraft, som forestillingen om den kreative by har haft. Under etiketten 'den kreative by' bidrager kunst og kultur på den måde til intens ejendomsspekulation og forvandles undervejs selv til biopolitisk kulturproduktion, hvor alle aspekter af livet aktiveres og sættes i arbejde, som når livsstile bliver varer, og forestillingsevnen kobles direkte til erhvervslivet med henblik på profitmaksimering. Som Florida karakteristisk for denne oplevelses $\varnothing$ konomiske lingo skriver i sin bog: "Menneskelig kreativitet er den ultimative økonomiske ressource" (Florida, 15). En sådan retorik falder fint i hak med en bredere igangværende udvikling, i hvilken immaterielt og 
affektivt arbejde spiller en mere central rolle i den kapitalistisk organiserede produktion, og hvor der er sket en omstrukturering af arbejdspladsen hen imod at udgøre en mere fleksibel og dynamisk arbejdsenhed (jf. Hardt \& Negri), hvor termer som kreativitet, autonomi og netværk spiller en central rolle. Som de franske sociologer Luc Boltanski og Ève Chiapello beskriver i deres Le nouvel esprit du capitalisme, er efterkrigstidens fordistiske organiseringsprincipper i den vestlige verden blevet erstattet af en netværksbaseret organisering, der er baseret på de ansattes initiativer og relative selvstyring og har til formål at producere stemninger, følelser og atmosfærer, snarere end traditionelle produkter, men hvis underside er prekaritet, stress og en eksplosion i brugen af antidepressiva. Den individuelle friheds præmis er arbejdsløshedens strukturelle vold, den individualistiske mikro-økonomi fungerer på baggrund af en armé af overflødige, som alle risikerer at blive indrulleret i.

Ifølge Boltanski og Chiapello er der tale om et historisk forløb, hvor en neoliberal managementindustri har tilegnet sig brudstykker af 1960'ernes kunstneriske protest mod det daværende fordistiske disciplinsamfund og implementeret disse fragmenter i en ny runde af kapitalistisk akkumulation. I denne udvikling har kunstverdenen spillet en vigtig rolle både som inspiration for nye arbejdsprocesser og som ny profitabel sektor. Som den italienske autonomia-filosof Paolo Virno skriver: "Inden for kulturindustrien, selv i den mest arkaiske form beskrevet af Benjamin og Adorno, kan man ane de tidlige tegn på en produktionsmåde, som senere i den postfordistiske æra bliver generel og får status af kanon" (Virno, 34). Konsekvenserne af dette forløb har været, at kunst og økonomi er smeltet stadigt mere sammen, og at kunstneren i mange sammenhænge har forvandlet sig til en art kulturel entreprenør, der er i stand til at skabe profit. Den engelske billedkunstner Damien Hirst er selvfølgelig det mest oplagte, omend også ekstreme eksempel på denne udvikling, hvor kunst ender med at være intet andet end en finansiel transaktion, og kunstneren kynisk overidentificerer sig med kapitalismen. Hinsides den vulgære Hirst og hans endimensionelle diamantdødningehoved, For the Love of God, spiller forestillingen om kunstens revolutionære kræfter ikke nogen stor rolle i kunsten, hverken $\mathrm{i}$ billedkunsten, på scenen eller i litteraturen. Når revolutionen endelig optræder som reference eller tema i kunsten, er det næsten altid som en historisk henvisning, ikke som en fremtidig mulighed. Hos billedkunstnere som Josephine Meckseper og filmskabere som Philippe Garrel isoleres det revolutionære som cool og i øjenfaldende fragmenter, der er løsrevet fra enhver nutidig praksis. I sådanne sammenhænge bliver tidligere revolutionære begivenheder forvandlet til løsrevne og tomme former, som kan appliceres på alt fra kunst og kulturelle artefakter til mode med henblik på salg. Revolutionen tematiseres eller æstetiseres, og kunsten tømmes fuldstændigt for kritisk indhold. Der er ganske vist kunstnere, der kaster sig ud i samtidens politiske begivenheder og forsøger at bruge kunsten som rum for urimelige og konsensusnedbrydende gestus, men sjældent vellykket: Das Beckwerk har eksempelvis svært ved at løsrive sig fra sin krops historie og risikerer dermed at ende langt fra den æstetiske systemkritik.

I dag fremstår hverken billedet eller ordet som specielt antagonistiske i forhold til den herskende orden, ingen af dem evner tilsyneladende systemkritik for ikke at tale om en mere omfattende subversion. Den relationelle æstetiks meget begræn- 
sede satsninger er et sigende udtryk for situationen. Her er avantgardernes begær efter en anden verden blevet erstattet med produktionen af "sociale mellemrum" (Bourriaud, 13). De relationelle værker gør det ifølge den franske kurator Nicolas Bourriaud muligt for beskueren at koncipere andre måder at interagere og samarbejde på. Mødet med kunsten tager nu form af en genbrugsbutik (Christine Hills Volksboutique), en bænk, der kommer røg ud af, når man sætter sig på den, (Jeppe Heins Smooking Bench) eller et måltid på et galleri (Rirkrit Tiravanijas Untitled). Den store afbrydelse er helt oplagt ikke ærindet her. Der sker en drastisk nedskalering af kunstens revolutionære prætentioner, når ferniseringen på et New Yorkgalleri eller en rygende bænk på et museum bliver kunstværket.

\section{Mikropolitiske sammenføjninger}

Der er heldigvis stadigvæk andre mindre tandløse muligheder til stede, når det handler om kunstens politiske potentiale og spørgsmålet om kunst og revolution. Den østrigske kunstteoretiker og filosof Gerald Raunig forsøger i sin bog Kunst und Revolution fra 2005 at udstikke en vej ud af denne misere hinsides relationel æstetik og deslige. Med støtte i et åbent, poststrukturalistisk revolutionsbegreb, som Raunig henter hos forfatterparrene Gilles Deleuze og Félix Guattari samt Michael Hardt og Antonio Negri, foreslår han at tænke forholdet mellem kunst og revolution som midlertidige overlapninger uden syntese. Som modsætning til avantgardens forsøg på at lade kunst og dagligliv smelte sammen i en samfundsomvæltning tilbyder Raunig en forståelse af kunst og revolution som "midlertidige overlapninger, mikropolitiske fors $\emptyset \mathrm{g}$ på transversal sammenkædning mellem kunstmaskiner og revolutionære maskiner, hvor begge lapper over hinanden, ikke for at opsluge hinanden, men for i stedet at indgå i en tidsligt begrænset konkret udveksling" (Raunig, 15-16). Under inddragelse af begivenheder som den sovjetrussiske forfatter Sergej Tretjakovs aktiviteter i en kolkhoz i 1928, hvor han bl.a. indsamlede penge til køb af traktorer og redigerede kollektivbrugets vægavis og den ny-brechtske østrigske teatergruppe VolxTheaterKarawanes antiracistiske og globaliseringskritiske teaterkampagner, analyserer Raunig, hvorledes kunstnerisk praksis og politisk aktivisme momentant interagerer og skaber et kortvarigt brud, hvad han altså kalder en specifik sammenføjning af kunst og revolution.

I forlængelse af Deleuze og Negri definerer han revolution som en maskinel montage af tre sammenhængende komponenter, nemlig opstand, modstand og konstituerende magt. Det væsentlige i den definition er distanceringen fra en klassisk marxistisk-leninistisk forståelse af revolution som erobringen af statsmagten, hvor en kadre af beslutsomme tager magten og igangsætter en overgangsfase, før det nye samfund bliver en realitet. I stedet for at forstå revolution som et spørgsmål om at tilegne sig statsmagten og etablere et proletariatets diktatur handler det om at tænke uden om staten til fordel for revolutionen som en "ufuldendt og ufuldendelig molekulær proces, [...] som dukker frem før staten" (23). Arbejdet og modstanden er nemlig, som Deleuze og Negri betoner, oprindelige og kommer før kapitalen og magten. ${ }^{4}$ Denne 'oprindelige' modstand risikerer at blive opslugt af den allerede konstituerede magt og kapitalismen, men er faktisk hele tiden i færd med at skabe 
et nyt samfund, nye flugtlinjer og er i færd med at blive-noget-andet, som Raunigs inspirationskilde, Deleuze skriver.

VolxTheaterKarawane står for Raunig som mønstereksemplet på den mulige sammenføjning mellem revolution og kunstmaskine, her kobles samfunds-, institutions- og selvkritik sammen, uden at kunst og politik forsøges ophævet. Der er snarere tale om en bevægelse på grænsen mellem de to diskurser. Raunigs fremstilling hører uden tvivl til noget af den mest interessante politiske kunstteori aktuelt, men forestillingen om de kortvarige og processuelle sammenføjninger mellem revolution og kunstmaskine tenderer til at gøre idéen om revolution meget luftig. Raunigs helt eksplicitte sammentænkning af kunst og revolution gør det muligt at udstille det reelt afpolitiserende i den såkaldt "politiske kunst og litteratur", der cirkulerer i samtidskunsten og den litterære institution. Det er godt. Men Raunigs betoning af det midlertidige risikerer at ende med at se ud som noget, der har ganske lidt med revolution at gøre. Hvis vi skal trække det hårdt op, kan vi måske gå så langt som til at sige, at vi her har at gøre med en politiseret udgave af Bourriauds relationelle æstetik, hvor mikropolitiske overlap skal gøre det ud for afviklingen af kapitalismen, dens statsform, pengeøkonomi og lønarbejde. Det er i hvert fald svært at se, hvordan Raunigs kunstmaskiner reelt skal kunne udgøre et dialektisk alternativ til noget som helst, hvis de hele tiden bare hopper videre, klipper og afbryder, som Deleuze og Guattari skriver (Deleuze \& Guattari, 7). At bevæge sig på grænsen er meget godt, men der sker ikke nogen reel kritik af kunsten som betydning uden virkelighed. Der er en stor risiko for, at den Deleuze-inspirerede betoning af det midlertidige ender med at fungere som bekræftelse af status quo nu blot peppet op med kortvarige afbrydelser og lidt mere skizofreni, altså endnu en omgang pseudorevolution. Og det er jo netop sådan, kapitalismen er: En konstant innovationsbevægelse, hvor tidligere etablerede fællesskaber og livssammenhænge afvikles og erstattes med nye, alle medieret af varen. Hvordan en revolutionær proces, der afvikler staten og pengeøkonomien og skaber nye subjekter, faktisk finder sted, fastholdes og praktiseres, skriver Raunig ikke meget om. Det er, som om Raunig reelt standser sin analyse hver gang, kunstmaskinen er lige ved at forvandle sig til en revolutionær maskine, og det er ellers præcis den overgang, det er interessant at få kortlagt og blive ved med at opsøge. At ende i kunsten - home safe? - kan ikke være målet. At forsøge at opholde sig i overgangen mellem kunst og politik tenderer til en bevægelse på stedet snarere end en revolutionær ageren. Men det er vel i overskridelsen af såvel kunsten som det politiske, at det revolutionære perspektiv manifesterer sig?

\section{Kommunisering}

En intens interesse for en sådan stillen spørgsmål til kunst og politik finder man til gengæld i en række kunstinstitutionelt meget marginale projekter, der på forskellig vis viderefører surrealismens og Situationistisk Internationales kritik af dagliglivet. Le comité invisible og miljøet omkring det nu nedlagte tidsskrift Tiqqun bygger videre på den radikale del af avantgardens dagliglivskritik i retning af, hvad de kalder kommunisering, der er den umiddelbare destruktion af de kapitalistiske produktionsrelationer og en afvisning af skuespilsamfundets identiteter inklusive 
arbejder, kunstner eller forfatter. ${ }^{5}$ Her forsøges kunsten overskredet af en revolutionær aktivitet, hvor teori og praksis er forenet.

Allerede surrealisterne havde sidst i 1920'erne en relativt udviklet kritik af kunsten og det politiske som autonome områder, der forvandler det menneskelige begær til abstraktioner. Hos Breton og de andre surrealister var der endnu tale om en intuitiv og etisk forestilling om et afgørende brud med det moderne kapitalistiske samfund og dets opdeling af livet, men der var ikke desto mindre en revolutionær stræben, som blev formuleret gennem en kritik af såvel eksistensens materielle som moralske og intellektuelle sider. Breton langede eksempelvis ud efter de på det tidspunkt i både øst og vest dominerende idéer om produktivisme - mennesket skal producere sig en ny fremtid - og krævede en afskaffelse af pengene. Som der står i Manifeste du surréalisme fra 1924: "Gid der måtte komme en tid, da poesien dekreterer pengenes tid forbi og alene bryder himlens brød for jorden" (Breton, 30). Breton og surrealisterne afviste intuitivt kapitalismens opdeling af livet i arbejde og dagligliv, kunst og videnskab. ${ }^{6}$ Med udgangspunkt i kunsten fornemmede de nødvendigheden af at gøre oprør mod kapitalens reelle dominans, den næsten totale tilegnelse af den menneskelige bevidsthed med henblik på at få penge til at avle penge, som Marx skriver i første bind af Das Kapital. Situationisterne førte denne kritik videre og gav den en mere klar antikapitalistisk form i rammen af, hvad de kaldte kritikken af dagliglivet. ${ }^{7}$ Med denne bliver det muligt for situationisterne at opretholde og intensivere mellemkrigstidsavantgardernes tilsidesættelse af kunstinstitutionen og ønske om at sætte kreativiteten fri i dagliglivet og kombinere det med den revolutionære traditions kritik af det moderne kapitalistiske samfund og dets stat og arbejde. Med baggrund i surrealisternes intuitive fors $\varnothing \mathrm{g}$ på at synliggøre et andet dagligliv viste situationisterne, at revolutionen slet ikke har noget at gøre med en gruppe bevæbnede mænd, der møder op foran parlamentet og tilegner sig statsmagten og annoncerer, at nu skal der ske noget nyt. Revolutionen er ikke en sådan adskilt politisk begivenhed, hvor nogen tager magten og lægger planer for, hvordan vi når frem til et andet samfund. Den russiske revolution havde tydeligt vist, at det ikke var nogen farbar vej. Situationisterne afviste derfor adskillelsen mellem midler og mål og præsenterede en forestilling om revolutionen som den umiddelbare forvandling af hele livet. "Et eneste arbejde er tilbage: At rekonstruere samfundet på et andet grundlag" (Internationale situationniste, 23). For situationisterne måtte revolutionen være en afsked med alle de adskilte sfærer og identiteter og en ophævelse af lønarbejdet og de varegjorte måder, vi lever på. ${ }^{8}$

Det er denne idé om kritikken af dagliglivet, hvor varens mediering af de måder, vi spiser på, vi tilegner os viden på, vi bevæger os på, og vi forholder os til hinanden på, afvises, som Le comité invisible gør til sin. Derved indskriver de sig i en længere romantisk antikapitalistisk tradition, der strækker sig fra Charles Fourier over Marx til Georg Lukács og videre, som anklager kapitalismen som civilisation for seksuel fattigdom, individualisme, flokmentalitet, fremmedgørelse fra naturen, destruktion af enhver fællesskabsfølelse og mediering af alle sociale relationer gennem pengeformen og teknik. Le comité invisibles analyse er stort set den samme hver gang, om end antallet af referencer er blevet betydeligt mindre gennem årene, fra de meget spekulative og teoretiske tekster i Tiqqun til den henvisningsløse og 
'lettere' L'insurrection qui vient. Men analysen er den samme: Vi lever i en politisk$\varnothing$ konomisk splittet verden, som fors øges forenet på billedniveau. Som der står i L'insurrection qui vient:

6f Der er ikke nogen social løsning på den nuværende situation. Først og fremmest fordi den flydende masse af miljøer, institutioner og individuelle bobler, som man ironisk benævner 'samfund', er uden konsistens, og dernæst fordi der ikke længere er noget sprog for de fælles erfaringer. (Le comité invisible, 9)

Skuespillet skaber fremmedgørelse, adskiller mennesker og tømmer dem for indhold. Det tomme menneske, som er resultatet af denne proces, benævnes i Tiqqun Bloom efter protagonisten i James Joyces roman Ulysses. ${ }^{9}$ Det spektakulære varesamfunds Bloom er beskuer til eget liv og uden agens til at gøre noget eller forandre samfundet, som desuden heller ikke hænger sammen, men er ved at gå helt fra hinanden. Depression, stress og ensomhed er dette samfunds kendetegn.

46 'I AM WHAT I AM'. Det er marketingsindustriens seneste tilbud til verden. [...] Årtiers idéer for at nå dertil, til en ren tautologi. JEG=JEG. Han løber på et løbebånd foran spejlet i sit motionscenter. Hun kører hjem fra arbejde i sin Smart car. Vil de møde hinanden? 'JEG ER HVAD JEG ER'. Min krop tilhører mig. Jeg er mig, og du er dig, og det går dårligt. [...] Diffus skizofreni. Eskalerende depression. Atomisering i paranoide partikler. [...] Desto mere jeg vil være Mig, desto mere har jeg fornemmelsen af et tomrum. [...] Det overalt tilstedeværende påbud om at 'være nogen' nærer den patologiske tilstand, som gør dette samfund nødvendigt. Påbuddet om at være stærk producerer den skrøbelighed ved hjælp af hvilken den håndhæves, og det i en sådan grad at alt synes at have en terapeutisk dimension, selv det at arbejde eller at elske. (Le comité invisible, 13-14)

Inspirationen fra filosoffen Giorgio Agamben, som sidst i 1990'erne var en del af miljøet omkring Tiqqun, er tydelig: Den spektakulære varekapitalisme er en konstant produktion af udskiftelige varegjorte identiteter, som begrænser eller direkte annullerer menneskets potentiale til at være noget andet eller slet ikke være defineret ved tilhørsforhold og prædikater overhovedet. Skuespillet har bemægtiget sig ikke blot menneskets produktive, men også kommunikative evner og har på den måde effektueret en hidtil uset grad af fremmedgørelse. Le comité invisibles diagnose er således en opdateret udgave af situationisternes marxistiske analyse af skuespilsamfundet, men der trækkes altså også på Agamben, Heidegger og Benjamin, Marcuse, den tidlige Lyotard, den italienske arbejderisme-filosof Mario Tronti og ultraleftister som Giorgio Cesarano. Le comité invisible indskriver sig derudover tydeligt i en mørk kunstpolitisk tradition, der inkluderer skikkelser som Baudelaire, Alfred Jarry, surrealisterne og situationisterne, der alle er karakteriseret af en særlig sort, endda satanisk humor, der konsekvent afviser optimisme som en kynisk refleks af borgerskabet. ${ }^{\text {10 }}$

Le comité invisible fremmaner således billedet af en tyndslidt socialitet og et hult menneske, som står helt afskrællet og nøgent omgivet af stadig flere varer. Og forsøgene på at fylde hullet intensiverer blot fremmedgørelsen. Den sociale 


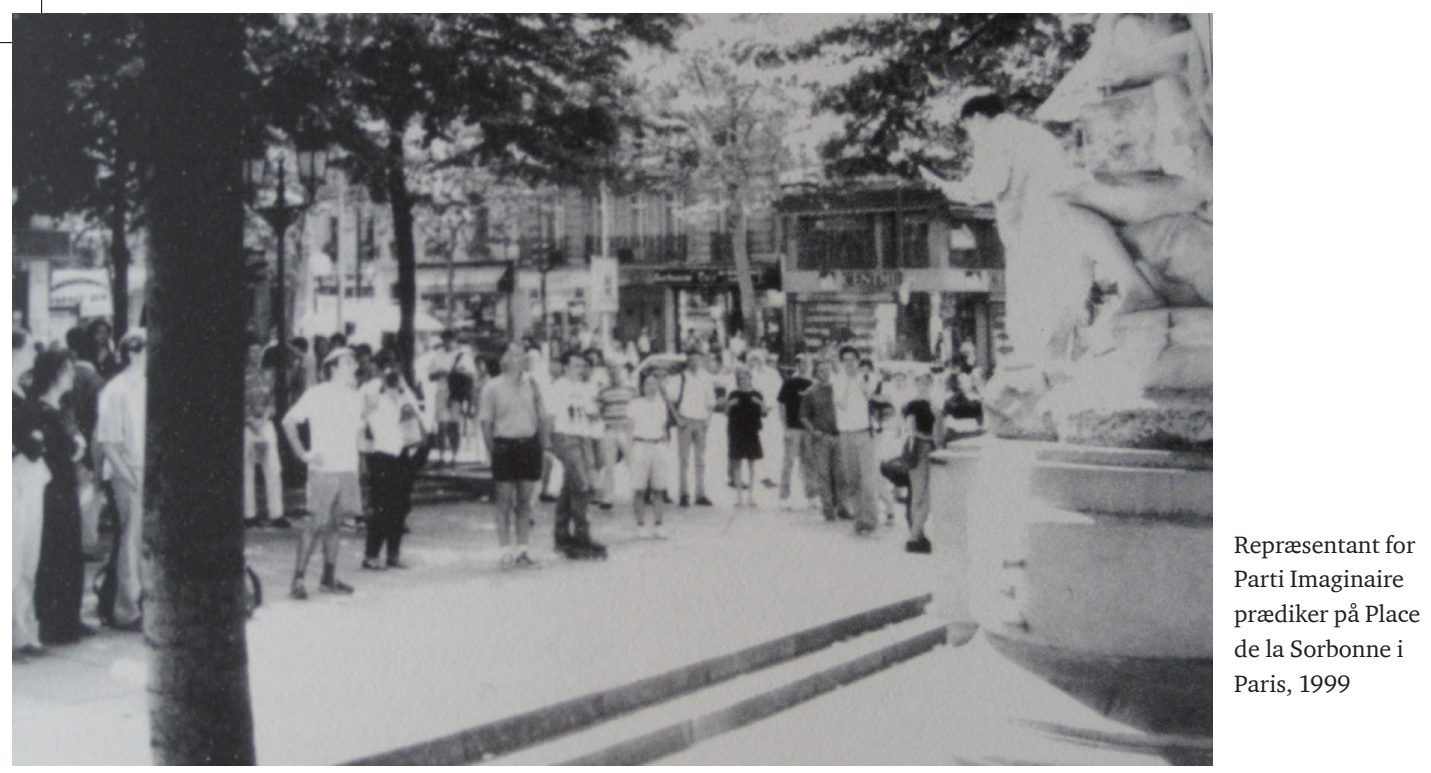

isolation forøges derfor hele tiden, når Bloom tager tilflugt i den uendelige række af forhåndenværende identiteter: bøsse, kunstner, racist, far, ekskluderet eller kristen. Bloom-mæssighedens smerte og fraværet af fællesskab forsøges desperat lindret med intens og kortvarig overidentifikation med de faldbudte vareidentiteter, som hver gang viser sig at nødvendiggøre et nyt identitetsfix. I en særegen venstreheideggeriansk sammentænkning af Guy Debord og Heidegger ved hjælp af Agamben opererer Le comité invisible således med en forestilling om, at Bloom er resultatet af forvitringen af en form for oprindelig fællesskabsfølelse. Derfor er Bloom hjemløs, kastet ud i ørkenen, forvist til konstant at bekræfte og forgæves overvinde sin individualitet, destineret til at reparere sin atomiserede monade-tilværelse med mere af det samme: Varegjorte 'forskelle' som enhver Bloom før eller siden køber.

Modsætningen til dette atomiserede ikke-liv er ikke skabelsen af et nyt fællesskab. I forlængelse af en særlig fællesskabsforestilling, som man blandt andet finder hos Georges Bataille, Maurice Blanchot og Agamben, skriver Le comité invisible om en form for værkløst fællesskab, Det Imaginære Parti, et fællesskab man ikke skal slutte sig til, ikke kan applaudere, som altid allerede findes, men som udhules og benægtes i skuespillets glinsende fitnesskroppe, der ser sig selv producere sig selv i spejlet i motionscentret. Hvis man skal henvise til tidligere sådanne anti-programprojekter, der forsøger at kombinere radikal kritik af eksisterende 'falske' fællesskaber med en holistisk satsning, der ikke kan tage form af et værk eller en politisk eller religiøs essens, kan man pege på det mystiske nietzscheanske fællesskab, Acéphale, som Georges Bataille stod bag sidst i 1930'erne (jf. Bolt 2010a). Hvor Acéphale - så vidt vi ved fra de få overleverede vidnesbyrd og sporadiske dokumenter, vi har mødtes under et tordenramt egetræ i en skov uden for Paris, nægtede at give hånd til antisemitter og planlagde en menneskeofring, der har Le comité invisible bl.a. holdt prædikener på Place de la Sorbonne, hvor de forsøgte at lægge sig ud med de forbipasserende: "De mest skarpsindige af jer vil fordømme en håndfuld korrupte lederes herredømme og tyranni, og de blinker med det ene øje. Men faktisk er jeres underkastelse hele sandheden om herredømmets verden. Det er ikke jer og 'systemet', dets diktatur, dets fattige og dets selvmord. Der er ikke andet end jer $i$ systemet, underkastede, blinde og skyldige" (Tiqqun 1999, 147). Derudover skal 
gruppen i sine tidlige år have praktiseret forskellige klassiske avantgardistiske aktioner som at læsse flere kilo lort af foran den ejendom, hvor dame- og modebladet 20 Ans har kontor eller skrive anti-Badiou-slogans over for Alain Badious lejlighed i Paris. Tiqqun-gruppen indgik også i den mere militante og kompromisløse del af de sene 1990'eres alterglobaliseringsbevægelse, som afviste forhandling med staten og i forbindelse med de store antitopmødeprotester i bl.a. Seattle, Prag og Genova ødelagde multinationale firmaers butikker og kontorer. ${ }^{\text {II }}$ De mere burleske aktioner vendt mod forskellige parisiske konkurrenter og/eller hadeobjekter og de militante aktioner på gaden synes dog efter 9/11 og den efterfølgende 'krig mod terror' at være blevet erstattet af et liv på landet uden mobiltelefoner, tv og anden moderne teknologi. Kriminaliseringen af alterglobaliseringsbevægelsen og fremkomsten af et nyt fjendebillede $\mathrm{i}$ form af islamisk terrorisme, som det var nødvendigt at distancere sig fra uden at bakke op om det kapitalistiske demokrati og dets eksklusionsstrukturer, nødvendiggjorde nye greb. Fouriersk eksodus og luddisme blev nu gruppens praksis hinsides Paris og antitopmødeprotester i et forsøg på at afvise alle allerede artikulerede politiske klassifikationer og skabe et rum, hvor det værkløse og ikke-aktivitet bliver sted for potentialitet. De halvobskure aktiviteter blev nu næsten helt usynlige, anonymiteten skal være vejen ud af skuespillets neutraliserende synlighed. At være uset er nemlig ifølge Le comité invisible at undslippe magten og langsomt undergrave den, glide ud af dens identifikationslogik og blive opak. Det betyder ikke en eksistens i marginen af samfundet, det er nemlig ikke muligt ifølge Le comité invisible, det er nødvendigt at afvise staten og alle de politiske, sociale og $\varnothing$ konomiske institutioner, som opretholder varen og lønarbejdet. Bevægelsen ind i usynligheden konciperes på den måde af Le comité invisible som en yderligere eskalering af kampen mod skuespillets underkastelse. Det er ikke muligt at leve med staten nogen steder, og det er illusorisk at forestille sig, at tingene en dag bliver anderledes uden kamp. Pointen er selvfølgelig, at den allerede er i gang, at skuespillet hele tiden bliver udfordret, ubønhørlig, med alle midler og fra alle sider. I Tiqqun blev denne tilstand beskrevet som en krig og en generaliseret undtagelsestilstand. Som der står i teksten "Thesès sur le Parti Imaginaire":

6f Ved at applicere sit fundamentale aksiom, ifølge hvilket det, der ikke ses, ikke eksisterer - esse est percipi - kan Skuespillet opretholde den uhyrlige og planetære illusion om en skrøbelig civil fred, hvis perfektionering fordrer, at man lader den udbrede sin gigantiske kampagne for pacificering af samfundene og neutraliseringen af deres modsætninger til alle domæner. Men dets forventelige nederlag er logisk indskrevet i det simple faktum, at denne pacificeringskampagne stadig er en krig - uden tvivl den mest skrækindjagende og $\varnothing$ delæggende, der nogensinde har været, da den føres i fredens navn. (Tiqqun 2010, 81)

Samfundet er så tyndslidt og usammenhængende, at alle midler tages i brug for at undgå det totale kollaps. Men Det Imaginære Parti og Den Usynlige Komité er allerede i færd med at undergrave skuespillet og "koordinerer i stilhed sabotage i stor stil" (Tiqqun 2000, 134). Denne omfatter alle mulige former for 'asocial adfærd' som 'umotiverede' voldelige udbrud, strejker, butikstyveri, depression, riots, hacking og terror. Alle er de ifølge Le comité invisible i virkeligheden udtryk for modstand mod skuespillet. 
64 Det er præcist i det omfang, katastrofen er sandheden i denne tilstand af højspændte glimt, at menneskene i det Imaginære Parti med alle midler arbejder for dens komme. [...] De er [...] i stand til frit at vælge scenen for deres operationer og handler dér, hvor minimale kræfter kan gøre stor skade. Det mest foruroligende er, at de ved det hele uden at vide, at de ved det. Således hælder en anonym arbejder på en aftapningsfabrik 'bare sådan' noget cyanid i en håndfuld dåser, en ung mand dræber en turist af hensyn til 'bjergets renhed' og underskriver sin forbrydelse 'FRALSEREN' [sic], en anden blæser 'tilsyneladende uden grund' hjernen ud på sin småborgerlige far på hans fødselsdag, en tredje åbner ild mod en flok af sine dygtige skolekammerater, en sidste kaster 'umotiveret' sten efter bilerne oppe fra broen over motorvejen, når han ikke brænder dem af i parkeringskældrene. (Tiqqun 2010, 91-92)

Der er en tydelig messiansk dimension over Le comité invisibles analyser, de omsiggribende ødelæggelser er redningen. Som hos Agamben har vi en variant af forestillingen om, at truslen og frelsen er intimt forbundne, at den voldelige negation følges af nåde, men en ubærlig sådan. Skuespillets misere er svanger med forløsning. Som der står i den første linje i L'insurrection qui vient: "Uanset fra hvilken vinkel man ser den, er nutiden uden udvej. Det er ikke det ringeste af dens fortrin" (Le comité invisible, 7). Kapitalismen er i en dyb krise, såvel økonomisk som økologisk og socialt, en krise den ikke kan komme ud af, og det giver derfor ikke mening at vente: Krigen er allerede i gang.

Le comité invisible nøjes således ikke med at hudflette den spektakulære varekapitalisme, den overvejer også, hvad der skal gøres. Betoningen af praksis er blevet tydeligere fra de tidligere mere metafysiske spådomskunster i Tiqqun til Linsurrection qui vient, hvor afskeden med den kapitalistiske by og dens teknologi præsenteres som et revolutionært greb.

"Dernier avertissement au Parti Imaginaire concernant l'espace public", 1999. Plakat opklæbet på offentlige bygninger i Paris.

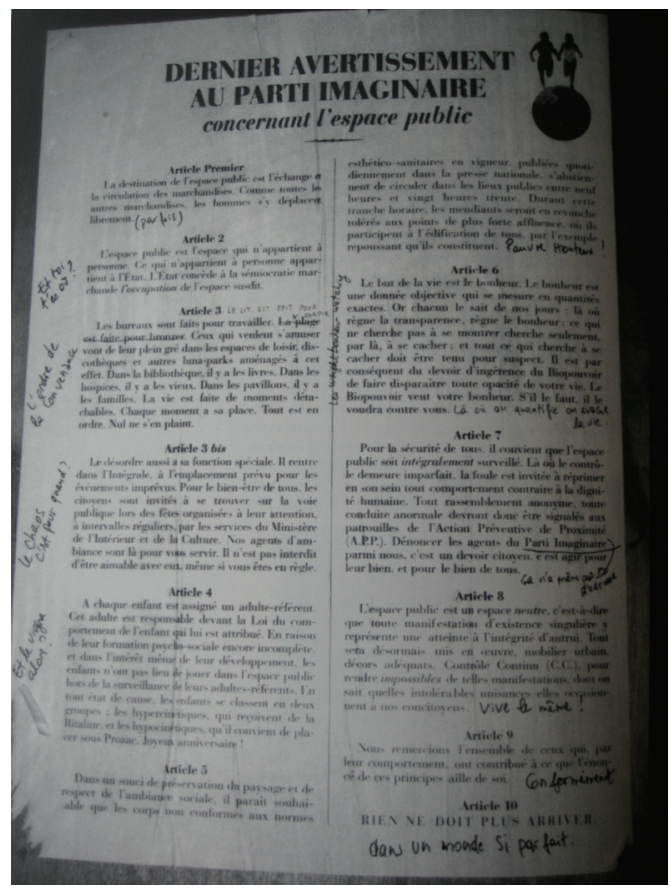


66 Der er ikke noget at vente på - en lysning, revolutionen, den nukleare apokalypse eller en social bevægelse. At vente længere er vanvid. Katastrofen er ikke det, der på vej, det er det, som er her. Vi placerer os straks og allerede $i$ civilisationens sammenbrudsbevægelse. Det er dét, man skal gøre. (Le comité invisible, 83)

Mens Marx' Feuerbach-teser ligger ligefor, er vi langt fra Žižeks nylige mantra om, at de revolutionære skal tænke og for guds skyld ikke handle (Žižek, 6). ${ }^{\mathrm{I2}}$ Over for en sådan position pointerer Le comité invisible, at det er muligt og nødvendigt at handle. Selvom skuespillet dækker det hele, er det muligt at intervenere og afbryde underkastelsen. Som der står i Appel, skal der etableres steder, hvor dem, der deserterer, kan søge beskyttelse og etablere udvekslingsfrie relationer hinsides skuespillet. Sådanne steder, som Le comité invisible kalder kommuner, eksisterer ikke allerede og skal ikke skabes, de etableres i det, der allerede findes. De er mutationer af det forefindende. Kommunen er ikke et nyt værk, man kan samles omkring, det er et sted, hvor der finder en radikal selvopløsning sted, hvor skuespillets identiteter som muslim, kunstner, kvinde og rocker ikke længere betyder noget, hvor den dominerende eksistentielle liberalismes personlige valg afvikles i en desubjektivering, hvor alle identiteter brækkes op, og de falske begær presses ud af kroppen. Det er et sted, hvor der udvikles nye former for subjektivitet, hvor det er muligt at tilfredsstille de begær, som den nuværende situation altid forbyder og fortrænger. Kommunen er således en art sammenføjning af de kommunistiske gestus, der allerede afviser kapitalismen nu og er ved at skabe en anden verden. "En kommune opstår hver gang, nogle stykker, som er blevet frigjort fra individualitetens spændetrøje, giver sig til kun at regne med sig selv og stiller op til kamp mod denne virkelighed" (Le comité invisible, 90).

Kampen mod den fuldendte adskillelse kan ikke finde sted gennem allerede etablerede miljøer, det være sig militante og kulturelle miljøer, eller inden for rammerne af politiske organisationer. Disse er reelt ifølge Le comité invisible blot en uendelig udsættelse af kampen. I kunstverdenen strander de revolutionære energier, der anbringer man de endnu ikke kvalte intensiteter. "Det litterære miljø findes for at kvæle det skrevnes virkelighed" (Le comité invisible, 88). De militante miljøer og de såkaldt revolutionære politiske organisationer udsætter konstant den revolutionære aktivitet til fordel for diskussioner af fortidens nederlag eller måder at holde organisationen i live på; når de endelig gør noget, ender de med at komme (velfærds)staten til undsætning, og de glemmer således, at staten og kapitalen hænger uløseligt sammen og begge skal ophæves. Le comité invisible definerer sig derfor, som situationisterne også gjorde det, som antipolitiske, de afviser de eksisterende politiske former, da disse netop er med til at opretholde den adskillelse mellem politik, kunst og dagligdag, skuespillet er baseret på. Bloom ved et eller andet sted godt, at de eksisterende former er rådne, det er da også derfor, han ikke gider engagere sig i dem. I stedet for at lade sig indrullere i disse miljøer er opgaven ifølge Le comité invisible, at alle Bloomer tilegner sig magten lokalt og skaber kommuner her og nu. Revolutionen skal netop ikke udsættes til engang i fremtiden, som de militante organisationer, Lenin og Slavoj Žižek siger. 
64 Enhver kommune skal udgøre sit eget grundlag. Den vil opløse spørgsmålet om behov. Den vil, samtidig med at den smadrer enhver økonomisk afhængighed, smadre enhver politisk underkastelse [...]. Der findes alle mulige forskellige kommuner, som ikke venter på tallene, ressourcerne eller 'det rigtige øjeblik' - som aldrig indfinder sig - før de organiserer sig. (Le comité invisible, 90-91)

For La comité invisible er revolutionen en kommuniseringsproces, som allerede er i gang som en destruktiv praksis i skuespillet. Som en proces hvor tingene gøres fælles, bruges og trækkes ud af kapitalens kredsløb. "At kommunisere noget betyder at frigøre dets brug og på baggrund af denne frigørelse udvikle forfinede, intensiverede og mere komplekse forhold" (Appel, 66). Det handler således ikke om først at tage magten og derefter skabe kommunisme. Le comité invisible afviser på det kraftigste en sådan forestilling om et program, der skal realiseres, eller et mål, som ligger langt ude i fremtiden. Kommunismen kan ikke udsættes. Hic Rhodus, Hic Salta! som Marx skriver (Marx 1976, 244). I forlængelse af ultraleftister som Jean Barrot understreger Le comité invisible, at kommunismen er en bevægelse, som allerede eksisterer, at kommunen både er middel og mål. ${ }^{13}$ Som i Pariserkommunen, hvor de sociale eksperimenter var i fuld gang med det samme og ikke blev udsat til efter krigen mod Thiers og den franske regering (jf. Bolt 2008). Der er derfor ikke nogen forestilling om en post-revolutionær tilstand eller glade morgener, hvor arbejderne er kommet hjem og er blevet sig selv. Arbejderen skal som danskeren og alle de andre identiteter sprænges i luften. Kun ved at tømme hovedet for billeder af, hvordan et bedre liv kan se ud, kan fremtiden blive mulig. Hvis der er håb i dette scenarium, er det således en form for tomt nihilistisk håb uden noget bestemt indhold.

Det er perspektivet for Le comité invisible: At affirmere nihilismen, finde det punkt hvor passivitet bliver aktivitet, hvor der sker et brud, og vi bliver en art kollektiv revolutionær subjektivitet hinsides adskillelsen mellem kunst og økonomi, politik og hverdagsliv, teori og praksis. Det er på den måde, Le comité invisible fortsætter den situationistiske avantgardes kritik af dagliglivet og forsøger at destruere kunsten som en adskilt sfære, som betydning uden virkelighed. Her er det ikke godt nok, at kunsten muligvis indeholder et løfte om lykke, nu skal det indfries. Adskillelsen skal fuckes up, Bloom smadrer motionscyklen, vælter ud i det fri, finder en guitar, giver den gas, og kommunen manifesterer sig som et Fouriersk punkband: "Don't know what I want. But I know how to get it."

\section{Noter}

I Allerede i Das älteste Systemprogramm des deutschen Idealismus fra 1796-1797 formulerer G.W.F.

Hegel, F. Hölderlin og F.W.J. Schelling et sådant projekt, hvor kunsten som en ny mytologi skal forene adskilte samfundssfærer som en art søskende. Som reaktion på borgerskabets afvikling af den ene feudale institution efter den anden, fik kunsten således til funktion at fungere som eller skabe en ny universalistisk overbygning. I kunsten var det muligt at realisere det fællesskab, som det frie marked ikke muliggjorde. Jf. Lypp og Bowie.

2 For analyser af avantgarderne som del af en bredere romantisk antikapitalisme, se Löwy og Sayre samt Schulte-Sasse. 
Still med Chloë Sevigny fra Get Rid of Yourself, 2003.

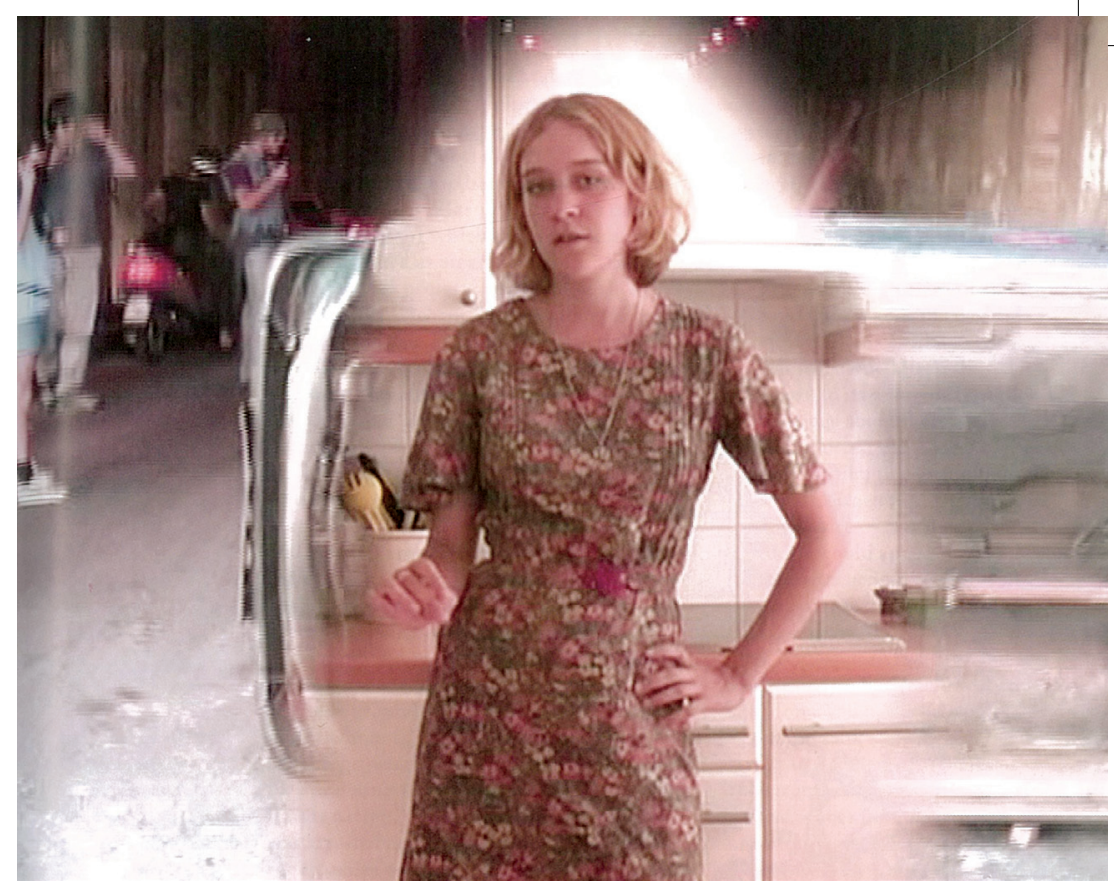

sociale pris for æstetisk autonomi” (Adorno, 339).

4 Deleuze overtager forestillingen om modstandens 'oprindelighed' fra Foucault (jf. Deleuze, 104). Det var Mario Tronti, som udviklede den for den italienske arbejderisme og Negri så vigtige idé om arbejdernes modstand, der er 'primær' i forhold til kapitalens strategi (jf. Tronti).

5 L'insurrection qui vient er den seneste udgivelse fra et neosituationistisk miljø, der har været aktivt i Paris siden slutningen af 1990'erne. Det første nummer af det A4-store tidsskrift Tiqqun udkom i 1999, og det andet og sidste nummer året efter. Tekster fra tidsskriftet er blevet genoptrykt som små bøger løbende. Gennem hele perioden frem til i dag er der udkommet små pamfletter og opråb, blandt andet Appel fra 2003. I 2001 blev der lavet en Guy Debordinspireret video, Et la guerre est à peine commence..., med en melankolsk hudfletning af den nuværende misere. I 2003 samarbejdede gruppen med den New York-baserede kunstgruppe Bernadette Corporation om produktionen af videoen Get Rid of Yourself!, som har været udstillet på en række udstillinger og turneret til filmfestivaler. Videoen handler om alterglobaliseringsbevægelsen, den store demonstration i Genova i 2001, hvor italiensk politi skød og dræbte Carlo Giuliani og gennemtævede hundrede af demonstranter, og (u)muligheden for militant kritik i dag. I 2007 udkom bogen L'insurrection qui vient signeret af Le comité invisible. Det er ikke ligetil at klarlægge den faktiske personkonstellation, der har været og er med i projektet. I det første nummer af Tiqqun optræder der en redaktionsgruppe, men ingen tekster er signeret, og i det næste nummer er alle navne væk. Alle de følgende tekster og produkter har enten været helt anonyme - som eksempelvis Appel, der hverken havde forfatter, forlag eller trykkested - eller signeret kollektivt som Le comité invisible eller Tiqqun. De fleste af gruppens efterladenskaber er tilgængelige online på: http://www.bloom0101.org/page1.html

Den 11. november 2008 stormede det franske antiterrorkorps en gård i landsbyen Tarnac og arresterede beboerne, en gruppe unge mellem 22 og 34 år som havde købt gården og startet en gårdbutik. Aktionen fandt sted under stor mediebevågenhed, og de unge blev efterfølgende anklaget for sabotage og terrorvirksomhed. Helt konkret gik anklagen på, at de ni skulle have saboteret TGV-tog ved at smide hesteskoformede jernstænger på togenes strømkabler, hvad der skulle have resulteret i forsinkelser af 160 tog. Blandt de anklagede var Julien Coupat, som ifølge den franske anklagemyndighed er hovedmanden bag aktionen, og som ifølge 
anklagemyndigheden har skrevet L'insurrection qui vient, som anklagemyndigheden kalder en manual i terrorisme. Coupat var med i redaktionen af Tiqqun. For en præsentation af hele forløbet omkring arrestationen, se Gay.

6 Som det er velkendt, forsøgte Breton og surrealisterne at slippe ud af det rent litterære felt ved at etablere et samarbejde med det franske kommunistparti, som imidlertid aldrig reelt lykkedes, både fordi kommunistpartiet så det som sin primære opgave at forsvare den stadig mindre revolutionære udvikling i Sovjetunionen, og fordi Breton med god grund aldrig accepterede kommunistpartiets ‘økonomisme’: Revolutionen kan ikke kun bestå i en materiel og økonomisk udbedring af den faktisk eksisterende ulighed, det drejer sig også om en hel række andre områder ikke mindst om at smadre rationaliteten (jf. Bolt 2004).

7 Se Gombin for en god præsentation af situationisternes kritik af dagliglivet.

8 Selvom situationisterne afviser forestillingen om, at kommunismen kan være arbejdernes styring af produktionsmidlerne, så opererer de stadigvæk med en idé om en ubesmittet proletarisk essens, som kan bringes frem i lyset i rådsformen (jf. Bolt 2006).

9 I Théorie du Bloom præsenteres Bloom således: "Det sidste menneske, manden på gaden, massemennesket, menneskemassen, det er således, at MAN først og fremmest har repræsenteret Bloom for os: Som det triste produkt af multitudernes periode, som den industrielle æras og fortryllelsens ophævelses katastrofiske søn. Men også i disse betegnelser kan man fornemme en skælven. Man ryster ved det almindelige menneskes uendelige mystik. Enhver fornemmer en ren potentialitet bag Blooms kvaliteter, en ren potentialitet det ikke er meningen, vi skal kende noget til" (Tiqqun 2000, 16-17).

Io Baudelaire betegner latter som satanisk: "Latteren er satanisk, den er altså dybt menneskelig. Den er i mennesket en konsekvens af forestillingen om sin egen overlegenhed; og eftersom latteren er menneskelig i sin natur, er den også dybt selvmodsigende i sit væsen; følgelig er den på én gang udtryk for en uendelig storhed og en uendelig elendighed" (Baudelaire, 50).

II For en præsentation af alterglobaliseringsbevægelsen og dens forskellige dele samt dens forvitring efter 9/11, se Bolt 2009.

I2 Som der står i den elvte Feuerbach-tese: "Filosofferne har kun fortolket verden forskelligt, men hvad det kommer an på er at forandre den" (Marx 1974, 16).

I3 I forlængelse af maj '68 og 1970'ernes wildcat strejker udviklede ultraleftistiske grupper som Mouvement Communiste med Barrot og La Guerre Sociale med Domenique Blaue en teori om revolutionen som kommunisering, det forhold at kommunismen skal være til stede $i$ revolutionen og ikke først indfinde sig som en senere fase. Inden for de seneste 5-6 år er der sket en aktualisering af begrebet i tidsskrifter som Théorie Communiste og Meeting. Hvor Le comité invisible supplerer referencerne til Debord og Marx med henvisninger til Heidegger og Agamben og i høj grad fokuserer på reproduktion og forbrug, der er Théorie Communiste og Meeting mere klassisk marxistiske i deres greb og fokuserer fortrinsvis på de kampe, der finder sted på arbejdspladsen. Således kritiseres Le comité invisible i Meeting karakteristisk for at mangle forestillingen om klassekamp i deres analyser. Ifølge Meeting er Le comité invisibles kommune "den glade glemsel og ikke den ubehagelige afskaffelse af klassesamfundet" (Meeting: 44).

\section{Litteratur}

Adorno, Theodor W. \& Max Horkheimer (1995): "Kulturindustri. Oplysning som massebedrag" ["Kulturindustrie. Aufklärung als Massenbetrug"], in: Oplysningens dialektik. Filosofiske fragmenter 
Gyldendal, pp. 179-238.

Adorno, Theodor W. (1998): Ästhetische Theorie [1972], Frankfurt: Suhrkamp.

Appel.

Barrot, Jean (1972): “Capitalisme et communisme”, in: Communisme et question russe, Paris: Éditions de la Tête de Feuilles, pp. 180-231.

Baudelaure, Charles (1994): "Om latterens væsen og i almindelighed om det komiske i den bildende kunst" ["De l'essence du rire et généralement du comique dans les arts plastique, 1855], oversat af Kirsten Jørgensen, in: Passage nr. 17, pp. 43-63.

Beckwerk (2009): Suverænen, København: Gyldendal.

Bolt, Mikkel (2004): “The Situationist International, Surrealism and the Difficult Fusion of Art and Politics", in: Oxford Art Journal, vol. 27, nr. 3, pp. 365-387

Bolt, Mikkel (2006): "Den spektakulära varuekonomin. Om situationisternas kapitalismkritik", oversat til svensk af Christian Nilsson, in: Ord \& Bild nr. 5, pp. 60-68.

Bolt, Mikkel (2008): “Alt skal væk! Kommunarderes nedrivning af Vendôme-søjlen”, in: Kontur nr. 18, pp. 19-28.

Bolt, Mikkel (2009): "En anden verden er mulig. Antiglobaliseringsbevægelsen og andre antisystemiske satsninger i retrospektiv", in: Lettre Internationale nr. 19, pp. 154-181.

Bolt, Mikkel (2010a): "Fraværet af et projekt. Bataille, Acéphale og det umulige fællesskab”, in: Mikkel Bolt \& Jacob Lund (red.): Fællesskabsfølelser. Kunst, politik, filosofi, Århus: Klim, pp. 15-38.

Bolt, Mikkel (2010b): “Adskilligt om samtidskunsten, dens modsætninger og vanskeligheder", in: Øjeblikket nr. 51, pp. 27-32.

Boltanski, Luc \& Ève Chiapello (1999): Le nouvel esprit du capitalisme, Paris: Gallimard.

Bourriaud, Nicolas (2005): Relationel æstetik [Esthetique relationelle, 1998], oversat af Morten Salling, København: Det Kongelige Danske Kunstakademi.

Bowie, Andrew (2003): Aesthetics and Subjectivity: From Kant to Nietzsche, Manchester: Manchester University Press.

Breton, André (1972): "Det første surrealistiske manifest" ["Manifeste du surréalisme”, 1924], in: De surrealistiske manifester, København: Gyldendal, pp. 13-60.

Breton, André \& Leo Trotskij (1980): "Pour un art révolutionnaire indépendant", in: José Pierre (red.): Tracts surréalistes et déclarations collectives. Tome I (1922/1939), Paris: Le terrain vague, pp. 335-339.

Bürger, Peter (1974): Theorie der Avantgarde, Frankfurt: Suhrkamp.

Deleuze, Gilles (2004): Foucault [1986], oversat af Karsten Gam Nielsen \& Kim Su Rasmussen, København: Det lille Forlag.

Gilles, Deleuze \& Félix Guattari (1972): L’anti-œdipe, Paris: Les Éditions de Minuit.

Deutsche, Rosalyn (2005): "Krystof Wodiczkos 'Hjemløs projektion' og den urbane genoplivnings sted" ["Krystof Wodiczko's 'Homeless Projection' and the Site of Urban Revitalization”, 1986], oversat af Erik Granly Jensen, in: Mikkel Bolt \& Karin Hindsbo (red.): City Rumble. Kunst, intervention og kritisk offentlighed, København: Overgaden - Institut for samtidskunst \& Forlaget politisk revy, pp. 60-115.

Erslev Andersen, Jørn (2009): “Virkeligheder. Manier. Realiteter”, in: Mikkel Bolt \& Jacob Lund (red.): Fællesskabsfølelser. Kunst, politik, filosofi, Århus: Klim, pp. 113-127.

Florida, Richard (2005): Den kreative klasse og hvordan den forandrer arbejde, fritid, samfund og hverdagsliv [The Rise of the Creative Class: And How it's Transforming Work, Leisure and Everyday Life, 2001], oversat af Joachim Wrang, Århus: Klim. 
Gay, Marcel (2009): Le coup de Tarnac. Les 9 de Tarnac, 'l'affaire Julien Coupat', l'utra-gauche, les sabotages SNCF, la piste allemande, les réseaux antinucléaires, les lois d'exception, Paris: Éditions Florent Massot.

Gombin, Richard (1971): Les origines du capitalisme, Paris: Seuil.

Hardt, Michael \& Antonio Negri (2003): Imperiet [Empire, 2000], oversat af Karsten Wind Meyhoff, København: Informations Forlag.

Harvey, David (2002): “The Art of Rent: Globalization, Monopoly and Cultural Production”, in: Leo Panitch \& Colin Leys (red.): Socialist Register 2002: A World of Contradictions, London: Merlin Press, pp. 93-110.

Hegel, George Wilhelm Friedrich, Friedrich Hölderlin \& Friedrich Wilhelm Joseph Schelling (1979): "Das älteste Systemprogramm des deutschen Idealismus" [1796-1797], in: G.W.F. Hegel: Werke. Band I, Frankfurt: Suhrkamp, pp. 234-237.

Internationale situationniste (1962): "Communication prioritaire", in: Internationale situationniste nr. 7, pp. 20-24.

Le comité invisible (2005): L'insurrection qui vient, Paris: La Fabrique.

Löwy, Michael \& Robert Sayre (1992): Révolte et mélancolie. Le romantisme à contre-courant de la modernité, Paris: Payot.

Lypp, Bernhard (1972): âsthetischer Absolutismus und politischer Vernunft. Zum Widerstreit von Reflexion und Sittlichkeit im deutschen Idealismus, Frankfurt: Suhrkamp.

Marcuse, Herbert (1979): “Über den affirmativen Character der Kultur" [1937], in: Herbert Marcuse: Schriften III. Aufsätze aus der Zeitschrift für Sozialforschung 1931-1941, Frankfurt: Suhrkamp, pp. 186-226.

Marx, Karl (1974): Den tyske ideologi [Die deutsche Ideologie, 1845-1846], oversat af Henriette Møller, København: Rhodos.

Marx, Karl (1976): Louis Bonapartes attende Brumaire [Der achtzehnte Brumaire des Louis Bonaparte, 1852], oversat af G. Jasper, in: Karl Marx \& Friedrich Engels: Udvalgte skrifter I, København: Forlaget Tiden, pp. 236-336.

Meeting (2005): “Un autre emploi de l'argent", in: Meeting nr. 2, pp. 41-47.

Peck, Jamie (2005): "Struggling with the Creative Class", in: International Journal of Urban and Regional Research vol. 29, nr. 4, pp. 740-770.

Raunig, Gerald (2005): Kunst und Revolution. Künstlerischer Aktivismus im langen 20. Jahrhundert, Wien: Verlag Turia + Kant.

Schulte-Sasse, Jochen (1987): "Imagination and Modernity: Or the Taming of the Human Mind", in: Cultural Critique nr. 5, pp. 23-48.

Tiqqun (1999): Tiqqun. Organe conscient du Parti Imaginaire: Exercices de Métaphysique Critique nr. 1. Tiqqun (2000): Théorie du Bloom, Paris: La Fabrique.

Tiqqun (2001): Tiqqun. Organe de liaison au sein du Parti Imaginaire: Zone d'opacité Offensive nr. 2. Tiqqun (2010): “Teser om det Imaginære Parti” [“Thèses sur le Parti Imaginaire”, 1999], oversat af Torsten Andreasen, in: Mikkel Bolt, Jakob Jakobsen \& Morten Visby (red.): Billed Politik. At se er at dræbe, København: Nebula.

Tronti, Mario (1966): Operai e capitale, Torino: Einaudi.

Virno, Paolo (2001): Grammatica della moltitudine. Per una analisi delle forme di vita contemporanee, Soveria Mannelli.

Žižek, Slavoj (2008): Violence, London: Profile Books. 